\begin{tabular}{|l|c|c|c|r|}
\hline $\begin{array}{l}\text { Cuadernos de Investigación Geográfica } \\
\text { Geographical Research Letters }\end{array}$ & 2017 & N $^{\circ} 43(2)$ & pp. 527-552 & $\begin{array}{r}\text { ISSN 0211-6820 } \\
\text { eISSN 1697-9540 }\end{array}$ \\
\hline
\end{tabular}

DOI: http://doi.org/10.18172/cig.3233

(C) Universidad de La Rioja

\title{
GLACIAL CHRONOLOGY OF THE SIERRA NEVADA, CALIFORNIA, FROM THE LAST GLACIAL MAXIMUM TO THE HOLOCENE
}

\author{
F. PHILLIPS*
}

Earth \& Environmental Science Department, New Mexico Institute of Mining \& Technology, 801 Leroy Place, Socorro NM 87801, USA.

\begin{abstract}
During the Last Glacial Maximum the Sierra Nevada in California, USA, supported a mountain glacier/ice cap complex that covered over 20,000 $\mathrm{km}^{2}$. The history of this ice cover can be reconstructed using ${ }^{14} \mathrm{C}$ and cosmogenic-nuclide surface-exposure dating. These show that the glaciers reached their maximum extent for the last glacial cycle between 21 and $18 \mathrm{ka}$, i.e., during the global Last Glacial Maximum. This is termed the Tioga 3 advance. A slow retreat began at $18 \mathrm{ka}$ and accelerated rapidly at about $17 \mathrm{ka}$. After retreating an unknown distance, the glaciers began to readvance at about $16.7 \mathrm{ka}$, reaching the Tioga 4 limit at $16.2 \mathrm{ka}$. They then rapidly retreated to the crest of the range, probably within 500 to 1000 years. There is no indication of subsequent glacial expansion until the Recess Peak advance between 14.0 and $12.5 \mathrm{ka}$. Unfortunately, chronological control is not adequate to determine whether this advance was during the early Younger Dryas or slightly preceded it. The equilibrium-line-altitude reduction during the Tioga 3 was about $1200 \mathrm{~m}$, during the Tioga 4 about $800 \mathrm{~m}$, and during the Recess Peak 100 to $200 \mathrm{~m}$. The Tioga 4 advance coincided with the expansion of nearby pluvial Lake Lahontan to its maximum size. The Sierra Nevada advances correlate well with the glacial chronology of the Alps during the same period, and also with the episodes of melting and advance of the European and Laurentide Ice Sheets. Times of glacial advance in the Sierra Nevada may be connected to the melting history of the ice sheets, and to Heinrich events, by expansion and contraction of sea ice in the southern North Atlantic.
\end{abstract}

\section{Cronología glaciar de Sierra Nevada, California, desde el Último Máximo Glaciar hasta el Holoceno}

RESUMEN. Durante el Último Máximo Glaciar(UMG), Sierra Nevada, California, USA, soportó un complejo manto de hielo que cubrió unos $20.000 \mathrm{~km}^{2}$. La historia de este manto de hielo puede ser reconstruida por medio de ${ }^{14} \mathrm{C}$ y datación por exposición a cosmogénicos. Los resultados muestran que los glaciares alcan- 
zaron su máxima extensión entre 21 y $18 \mathrm{ka}$, es decir, durante el UMG global, denominado avance de Tioga 3.Un retroceso lento empezó en 18 ka y se aceleró rápidamente hacia $17 \mathrm{ka}$. Después de retroceder una distancia desconocida, los glaciares iniciaron un reavance hacia aproximadamente $16,7 \mathrm{ka}$, alcanzado el límite de Tioga 4 en 16,2 ka. Luego retrocedieron rápidamente hasta la cresta de la cordillera, probablemente en el plazo de 500 a 1000 años. No hay nuevas evidencias de expansión glaciar posterior hasta el avance de Recess Peak entre 14 y 12,5 años. Desafortunadamente, el control cronológico no es adecuado para determinar si este avance ocurrió durante el Younger Dryas o lo precedió. La reducción de la línea altitudinal de equilibrio fue de unos 1200 m durante Tioga 3, de unos 800 m durante Tioga 4 y de 100 a 200 m durante el Recess Peak. El avance de Tioga 4 coincidió con la expansión del lago Lahontan hasta su máxima extensión. Los avances de Sierra Nevada se correlacionan bien con la cronología glaciar de los Alpes durante el mismo periodo, y también con los episodios de fusión y avance de los inlandsis europeo y lauréntide. Los periodos de avance glaciar en Sierra Nevada pueden conectarse con la historia de la fusión de los inlandsis y los eventos Heinrich, por expansión y contracción del hielo marino en el Atántico Norte meridional.

Key words: Sierra Nevada California, deglaciation, Marine Isotope Stage 2, glacial chronology, teleconnections.

Palabras clave: Sierra Nevada California, deglaciación, Estadio Isotópico Marino 2, Cronología glaciar, teleconexiones.

Received: 3 February 2017 Accepted: 4 April 2017

* Corresponding author: Fred Phillips, Earth \& Environmental Science Department, New Mexico Institute of Mining \& Technology, 801 Leroy Place, Socorro NM 87801, USA.E-mail address: Fred.Phillips@nmt.edu

\section{Introduction}

The Sierra Nevada parallels the coastline of California for about $600 \mathrm{~km}$ with maximum elevations that range from about $2000 \mathrm{~m}$ in the north to $4400 \mathrm{~m}$ close to the southern end. The highest point in the range is Mount Whitney at $4418 \mathrm{~m}$. The bulk of the range is a Mesozoic granitic batholith created in a back-arc environment behind the convergent plate boundary that existed off the California coast at that time. The northern end of the range has a thick cover of Cenozoic volcanic rock over granitoids while the southern portion in places exhibits a veneer of metamorphosed sedimentary and volcanic rock from the roof of the batholith. The batholith has been tilted westward as a rigid block due to sediment loading on the western margin and rift-style faulting on the eastern one (Small and Anderson, 1995; Phillips, 2008; McPhillips and Brandon, 2012). This has resulted in a gentle western slope characterized by broad uplands and a steep eastern slope with deep, narrow valleys. 
During the glacial maxima of the Pleistocene most of the crest and western highlands were covered by small ice caps and valley glaciers (Fig. 1). Combined, these covered an area of about $20,000 \mathrm{~km}^{2}$ (Moore and Moring, 2013). The general lower limit of glaciation ranged from $1500 \mathrm{~m}$ in the north up to $2500 \mathrm{~m}$ in the south, with the termini of the largest west-flank glaciers extending below $1000 \mathrm{~m}$. These glaciers shrank rapidly following the Last Glacial Maximum. Historically the Sierra Nevada has contained about 500 glaciers (Raub et al., 2006) that cover less than $50 \mathrm{~km}^{2}$. These are all located in sheltered cirques where topographic shading renders the energy balance favorable; even at the highest points of the range the present-day mass balance is negative for unshaded surfaces (Plummer, 2002). These diminutive bodies of ice are largely a result of neoglaciation during the last 3000 years; during the middle Holocene the range was probably nearly unglaciated (Bowerman and Clark, 2011).

The pattern of glaciation was strongly influenced by the climate of the range. The region exhibits a classic Mediterranean climate, with hot, dry summers and cool, but not cold, and wet winters. Annual precipitation is highest at the north end of the range, reaching $1300 \mathrm{~mm}$ there, and decreasing to $800 \mathrm{~mm}$ in the south. There is also a strong precipitation gradient from west to east due to the prevailing airflow northeastward from the Pacific Ocean. Precipitation increases eastward from the western base of the range due to the moist Pacific air being forced upward along the topographic slope. In the central and southern Sierra precipitation (and snowfall) reaches a maximum of $\sim 2000 \mathrm{~mm}$ at about $3000 \mathrm{~m}$ elevation. However, this precipitation maximum occurs at only about one-half the width of the range even though elevation continues to increase eastward to 3500 to $4000 \mathrm{~m}$ on the crest, where annual precipitation falls to about $1200 \mathrm{~mm}$. The decrease is due to water-vapor depletion of the air masses as they continue to be forced upward. East of the crest, in the rain shadow of the range, precipitation decreases markedly with decreasing elevation, declining to $150 \mathrm{~mm}$ on the floor of the Owens Valley. In the northern Sierra Nevada maximum precipitation is encountered on the crest of the range due to the lower elevation of the crest there.

Presumably the Pleistocene distribution of precipitation was generally similar to the modern one, since the Pacific Ocean is the only nearby source of abundant water vapor. The pattern of heaviest precipitation on the western fringe of the glacier basins must have created quite unstable glacier mass balances. A small decrease in temperature would have added large amounts of snow to the portions of the glacier near the equilibrium line altitude (ELA), whereas a small increase would have produced a large negative change in the glacier mass balance. The glacier snouts would have oscillated greatly in response. In contrast, on the east side of the range precipitation decreases monotonically with elevation and thus precipitation near the ELA was modest compared to that at the highest elevations. Small changes in temperature would therefore have much more modestly affected the glacier mass balance. This may explain why the lower reaches of canyons on the east side are characterized by monumental lateral moraines (Blackwelder, 1931) whereas on the western slope they tend to be unimpressive and to form scattered bands of till (Matthes, 1930; Birman, 1964). Greater stability of the glacier termini on the eastern slope allowed till to accumulate to great thickness. Unstable termini on the western slope spread the till over a wide region, resulting in thinner and less impressive moraines. 
The combination of decreasing range-crest elevation toward the north (and hence decreased topographic reduction of temperature) with the general decrease in temperature due to latitude causes a complex pattern of temperature along the crest. Maximum and minimum annual temperatures decrease from $15^{\circ} \mathrm{C}$ and $2{ }^{\circ} \mathrm{C}$ at the south end to $5^{\circ} \mathrm{C}$ and $-5{ }^{\circ} \mathrm{C}$ in the central section, then increase again to $12{ }^{\circ} \mathrm{C}$ and $-1{ }^{\circ} \mathrm{C}$ in the north (Moore and Moring, 2013). This is due to the normal decrease in temperature with increasing latitude combined with relatively constant and high elevation of the crest in the southern and central parts of the range, but elevation of the crest decreasing markedly with latitude in the northern part. The central section of the range was thus glaciated much more heavily than either of the ends (Fig. 1).

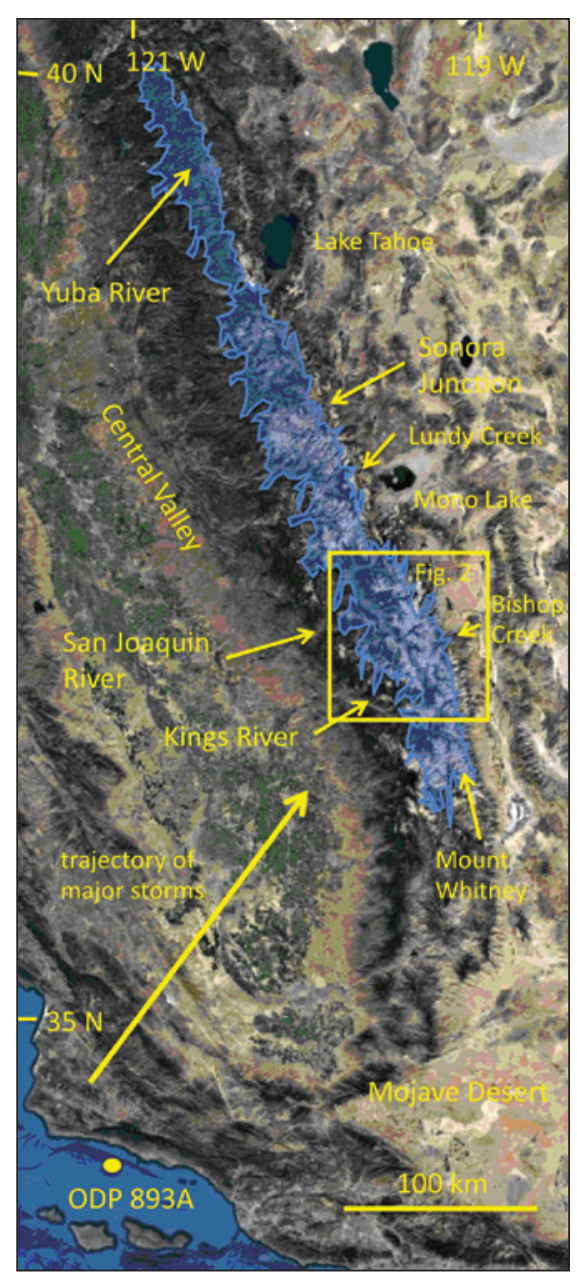

Figure 1. Satellite image showing the Sierra Nevada in California. Maximum area covered by Tioga ice (Clark et al., 2003) is in blue, with locations mentioned in text shown and the location of Ocean Drilling Program Core 893A and major storm trajectory (Pandey et al., 1999) shown. 


\section{Previous studies}

Evidence for formerly extensive glaciation was noted by the earliest geological observers of the Sierra Nevada (King, 1878; Russell, 1889; Turner, 1900; Knopf, 1918). These noted that evidence based on moraine morphology and relative weathering indicated that there had been more than one episode of glaciation of the range, but the classical systematic delineation of the glacial sequence was the work of Blackwelder (1931) on the east side and Matthes $(1929,1930)$ on the west side. Because the moraines on the east side are generally much larger and easier to distinguish than those on the west, and are also vegetated principally by low-standing sagebrush whereas the westslope ones are typically covered by pine forest that renders them difficult to visualize, the terminology of Blackwelder (1931) has generally been adopted for the entire range.

Blackwelder (1931) divided the glacial deposits into four stages. Starting with the oldest, they are the McGee, the Sherwin, the Tahoe and the Tioga. Based on subsequent research the McGee is probably Pliocene or early Pleistocene, the Sherwin dates to $800 \mathrm{ka}$, the Tahoe to $\sim 150 \mathrm{ka}$, and the Tioga to the Last Glacial Maximum (LGM) (Gillespie and Clark, 2011). The Tioga is thus the only one of Blackwelder's classical sequence that is pertinent to the topic of this paper. Two additional glaciations were later added by Sharp and Birman (1963): the Mono Basin and Tenaya, for which the type site was Bloody Canyon in the Mono Basin (central eastern Sierra). Although the age of the Mono Basin is uncertain (Gillespie and Clark, 2011), it is clearly pre-LGM. Phillips et al. (1990, 1996) dated the mapped Tioga and Tenaya moraines at Bloody Canyon and obtained an age in the late part of the last glacial cycle for the Tenaya moraine. They therefore considered it, at this location at least, to be part of the Tioga glaciation rather than a distinct one. Further additions were made by Birman (1964), who mapped moraines in the headwaters of Mono Creek (west slope) and Rock Creek (east slope) that he termed Hilgard and Recess Peak. He assigned both of these to the late Holocene. Subsequent work has demonstrated that the Recess Peak is in fact latest Pleistocene (Clark and Gillespie, 1997; Clark et al., 2003). Since the Hilgard lies outside of the Recess Peak, but within the zone where cosmogenic surface exposure ages have yielded ages close to the youngest Tioga moraines (Nishiizumi et al., 1989; Phillips et al., 2009), the Hilgard must represent a very late and minor Tioga deglacial oscillation. It is not now generally considered to be a separate glacial advance (Gillespie and Clark, 2011). Sierra Nevada glacial geology and chronology has been reviewed by Wahrhaftig and Birman (1965), Fullerton (1986), Gillespie et al. (1999), Osborn and Bevis (2001), Clark et al. (2003), Gillespie and Zehfuss (2004), Gillespie and Clark (2011), and Phillips (2016).

\section{Chronology for the deglaciation of the Sierra Nevada following the Last Glacial Maximum}

Figure 2 illustrates in blue the approximate limits of glacial extent during the LGM in the central section of the Sierra Nevada. Evidence reviewed in Gillespie and Clark (2011) shows that Sierra Nevada glaciers over the Pleistocene repeatedly advanced to similar maximum glacial limits. The most straightforward inference from this observation is that the numerous Pleistocene glacial/interglacial cycles must have 


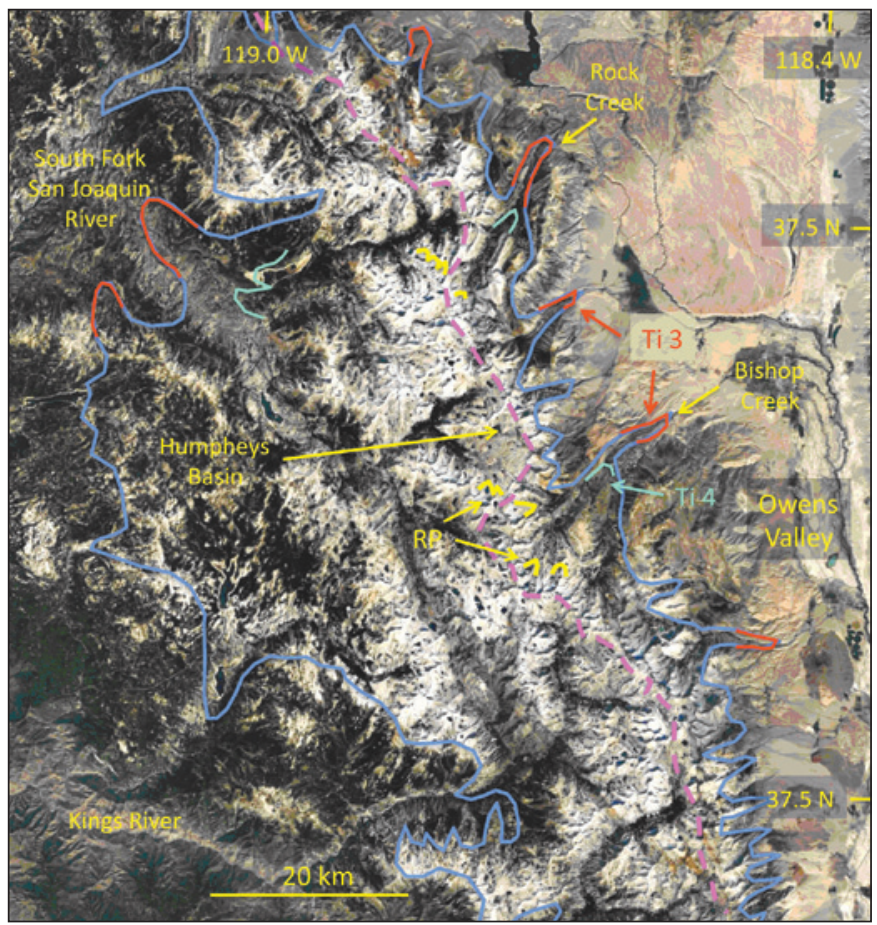

Figure 2. Late Glacial stages in the central Sierra Nevada, showing the relative extent of the various advances. The approximate maximum limits of Tioga glaciers are shown in blue, with selected mapped Tioga 3 moraines in red, Tioga 4 moraines in turquoise, and Recess Peak (RP) moraines in yellow. Mapping is from Birman (1964), Bateman (1965), Sharp (1969), and Phillips et al. (2009). Glaciation limits are from Clark et al. (2003). The dashed purple line indicates the

Sierra Nevada crest.

produced similar climatic conditions during the glacial maxima. The most recent cycle was no exception; the maximum extent of the Tioga glacial deposits is similar to, although usually slightly smaller than, older moraines in the same valleys. Figure 2 also illustrates the positions of the glacier termini in selected valleys during the recognized deglacial advances: the Tioga 4, and Recess Peak. These positions are based on mapping by earlier investigators who did not have the capability for quantitative chronology in their time (Birman, 1964; Rinehart, 1964; Bateman, 1965b; Bateman and Moore, 1965; Sharp, 1969; Bateman and Wones, 1972).

\subsection{Methods}

The timing of Tioga advances has been constrained by both radiocarbon and cosmogenic surface exposure dating subsequent to the original mapping. No organized campaign of radiocarbon dating has been undertaken in the Sierra Nevada, but Phillips (2016) assembled nine radiocarbon ages from various studies that provide a starting point for understanding the deglacial chronology of the range; these are shown in Figure 
3(a). Details on sample locations and significance can be found in Table 1 of Phillips (2016). These can be supplemented by a number of cosmogenic surface-exposure dating studies (Nishiizumi et al., 1989; Phillips et al., 1990; Phillips et al., 1996; Evans et al., 1997; James et al., 2002; Phillips et al., 2009; Dühnforth et al., 2010; Rood et al., 2011). Results from some of these studies were critically examined by Phillips et al. (2016b). Representative cosmogenic dating results from selected sites that exhibited tight clustering of data are included in Figure 3(a).

Table 1. Revised ages of cosmogenic nuclide samples from Sierra Nevada.

\begin{tabular}{|c|c|c|c|c|}
\hline Sample No. & Advance & Age (ka) & $\pm(\mathbf{k a})$ & $\begin{array}{c}\text { THAR ELA } \\
(\mathrm{m})\end{array}$ \\
\hline \multicolumn{5}{|c|}{ Bishop Creek Terminal (BCT) $\left({ }^{36} \mathrm{CI}\right.$, Phillips et al., 2009) } \\
\hline BPCR90-24 & Ti3 & 18 & 2.2 & 2630 \\
\hline BPCR90-73 & Ti3 & 18.7 & 1.8 & 2630 \\
\hline BPCR90-74 & Ti3 & 18.9 & 2.8 & 2630 \\
\hline BPCR90-75 & Ti3 & 20.5 & 1.7 & 2630 \\
\hline BPCR91-1 & Ti3 & 19.2 & 1.9 & 2630 \\
\hline BPCR91-3 & Ti3 & 19.6 & 1.9 & 2630 \\
\hline BPCR91-4 & Ti3 & 19.2 & 2.2 & 2630 \\
\hline \multicolumn{5}{|c|}{ Bishop Creek Confluence (BCC) $\left({ }^{36} \mathrm{CI}\right.$, Phillips et al., 2009; Phillips, 2016) } \\
\hline BpCR97-9 & Ti4 & 16.1 & 1.8 & 2930 \\
\hline BpCR97-13 & Ti4 & 16.5 & 1.8 & 2930 \\
\hline BpCR97-14 & Ti4 & 15.8 & 1.9 & 2930 \\
\hline BpCR97-15 & Ti4 & 16.0 & 1.9 & 2930 \\
\hline \multicolumn{5}{|c|}{ Humphreys Basin (HB) $\left({ }^{36} \mathrm{CI}\right.$ Phillips et al., 2009; Phillips, 2016) } \\
\hline HB97-1 & End $\mathrm{Ti} 4$ & 15.0 & 1.2 & 3600 \\
\hline HB97-2 & End $\mathrm{Ti} 4$ & 16.2 & 1.5 & 3600 \\
\hline HB97-3 & End $\mathrm{Ti} 4$ & 15.1 & 1.3 & 3600 \\
\hline HB97-4 & End $\mathrm{Ti} 4$ & 14.4 & 1.6 & 3600 \\
\hline HB97-5 & End $\mathrm{Ti} 4$ & 14.8 & 1.3 & 3600 \\
\hline \multicolumn{5}{|c|}{ Bishop Creek - Baboon Lakes (BCBL) ${ }^{36}$ CI Phillips et al., 2009; Phillips, 2016) } \\
\hline BpCR97-12 & $\mathrm{RP}$ & 13.7 & 1.2 & 3500 \\
\hline BPCR96-6 & $\mathrm{RP}$ & 10.5 & 1.5 & 3500 \\
\hline BPCR96-9 & $\mathrm{RP}$ & 11.0 & 1.3 & 3500 \\
\hline BPCR96-7 & $\mathrm{RP}$ & 11.7 & 1.1 & 3500 \\
\hline \multicolumn{5}{|c|}{ Sonora Junction Tioga, northern lobe (SJ) $\left({ }^{10} \mathrm{Be}\right.$, Rood et al., 2011) } \\
\hline SJTIR06-1 & Ti3 & 20.7 & 1.6 & 2540 \\
\hline SJTIR06-2 & Ti3 & 20.8 & 1.6 & 2540 \\
\hline SJTIR06-3 & Ti3 & 21.5 & 1.6 & 2540 \\
\hline SJTIR06-4 & Ti3 & 20.8 & 1.6 & 2540 \\
\hline SJTIR06-5 & Ti3 & 20.4 & 1.6 & 2540 \\
\hline SJTIR06-6 & Ti3 & 21.0 & 2.0 & 2540 \\
\hline
\end{tabular}




\begin{tabular}{lcccc}
\hline \multicolumn{2}{l}{ Lundy Tioga outwash $(\mathrm{LO})\left({ }^{10} \mathrm{Be}\right.$, Rood et al., 2011$)$} \\
LCTI0-07-01 & Ti3 & 18.3 & 1.3 & 2700 \\
LCTI0-07-02 & Ti3 & 14.5 & 1.3 & 2700 \\
LCTI0-07-03 & Ti3 & 18.9 & 1.3 & 2700 \\
LCTI0-07-04 & Ti3 & 19.5 & 1.6 & 2700 \\
LCTI0-07-05 & Ti3 & 19.6 & 1.6 & 2700 \\
LCTI0-07-06 & Ti3 & 18.9 & 1.3 & 2700 \\
Nishiizumi terminal Tioga samples (NTT) & $\left({ }^{10} \mathrm{Be}\right.$, Nishiizumi, 1989; Phillips, 2016) \\
W86-1 & End Ti 4 & 14.8 & 1.8 & 3500 \\
W86-4 & End Ti 4 & 15.3 & 1.5 & 3500 \\
W86-5 & End Ti 4 & 15.0 & 1.7 & 3500 \\
W86-6 & End Ti 4 & 15.2 & 1.8 & 3500 \\
W86-8 & End Ti 4 & 15.0 & 2.2 & 3500 \\
W86-11 & End Ti 4 & 15.1 & 1.7 & 3500 \\
W86-12 & End Ti 4 & 16.5 & 4.1 & 3500 \\
\hline
\end{tabular}

Both the methodology for calculating cosmogenic exposure ages and the parameter values have changed significantly through the 28 years since the publication of Nishiizumi et al. (1989). In order to make the ages used in this paper up to date and consistent, ages were recalculated using the original data entered into the CRONUScalc on-line calculator (Marrero et al., 2016a). These recalculated ages are given in Table 1. An accuracy check on the CRONUScalc calibration for ${ }^{10} \mathrm{Be}$ has shown that samples from North America yield ages that are consistently too old (Phillips et al., 2016a). Based on the results from the North American sites, excluding samples from the Sierra Nevada to avoid circularity, the average normalized age (i.e., ${ }^{10} \mathrm{Be}$ age divided by independently constrained age) was 1.091 (Phillips et al., 2016a) (the specific sites were Promontory Point, New England, and Puget Sound.) The recalculated ages for this study were therefore divided by 1.091 to correct for this bias. Chlorine-36 ages were not corrected in this way because they did not show consistent bias (Marrero et al., 2016b). The uncertainties given in Table 1 are total uncertainties, including uncertainty in production rates. This is appropriate for comparison with global climate records, but for comparisons between glacial features of different ages or localities in the study area the internal uncertainties, which average to 1200 years, are more appropriate.

Radiocarbon ages were converted to calibrated years using the IntCal13 data set, as implemented by the CALIB 7.1 program (Stuiver and Reimer, 1993; Reimer et al., 2013). Only calibrated ages are given in this paper.

In Figure 3(a) the various ages for glacial events are plotted against the ELA calculated for the position at which the materials were sampled. The ELA's were calculated using the toe-to-headwall altitude ratio (THAR) method (Charlesworth, 1957; Porter, 1964):

$$
E L A=Z_{\text {tos }}+C_{\text {THAR }}\left(Z_{\text {headwall }}-Z_{\text {tos }}\right)
$$




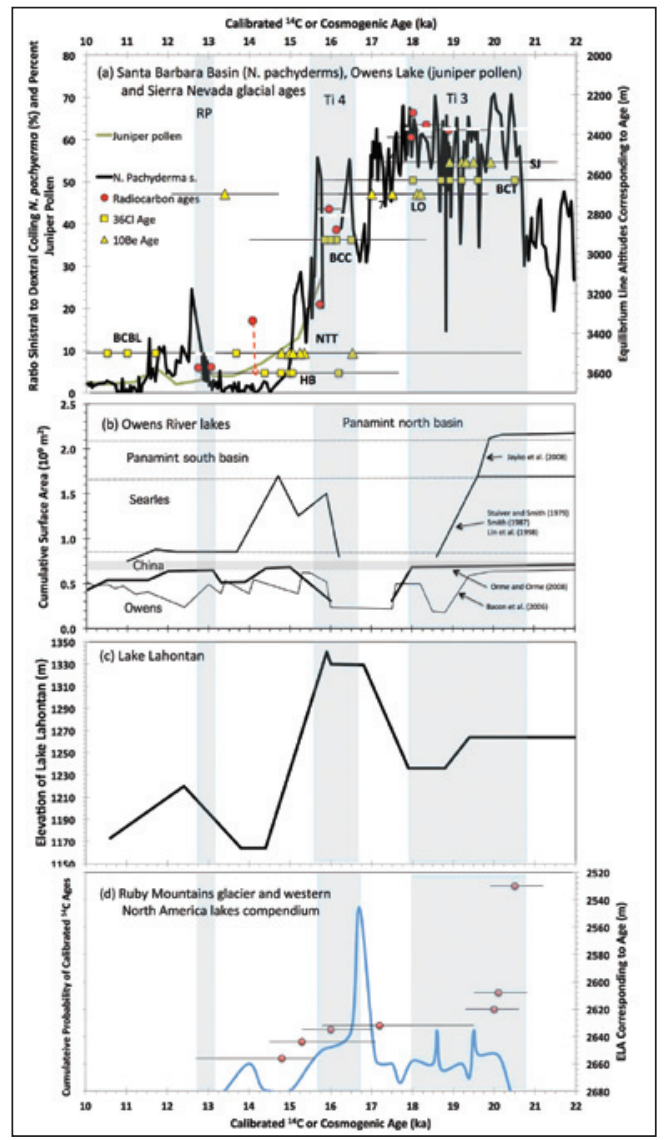

Figure 3. Chronology of ELA fluctuations in the Sierra Nevada and comparison to regional paleoclimate records. (a) Comparison of ${ }^{14} \mathrm{C}$ and cosmogenic ages for Tioga 3 (Ti 3), Tioga 4 (Ti 4), and Recess Peak (RP) advances. The calibrated ${ }^{14} \mathrm{C}$ ages are from Table 1 in Phillips (2016) and the cosmogenic-age site abbreviations and data sources are given in Table 1 of this paper. Corresponding ELA's were calculated using the THAR method, as described in the text. The black line shows the percentage of sinistral-coiling $N$. pachyderma in ODP Core 893A, from Hendy et al. (2002), but plotted on the revised time scale of Kennett et al. (2008). Upward on the graph corresponds to colder sea-surface temperature. The green line is the percentage of juniper pollen in cores from Owens Lake, with increasing juniper an indicator of colder temperature (Mensing, 2001). (b) Comparison with reconstructions of the cumulative surface area of closedbasin lakes in the Owens River system, based on Phillips (2008). The thin horizontal lines are the cumulative lake area at the overflow sills of the respective basins. The thick line is the sill range for the Owens Lake sill, which probably was not stable. Data for Panamint Valley are from Jayko et al. (2008), for Searles Lake from Stuiver and Smith (1979), Smith (1987), and Lin et al. (1998), and for Owens Lake from Bacon et al. (2006) (thin black line) and Orme and Orme (2008) (thick black line). (c) Lake surface elevation history for Lake Lahontan, from Reheis et al. (2014). (d) The solid blue line is the cumulative probability distribution (i.e., the sum of the normal probability distributions specified for each ${ }^{14} \mathrm{C}$ age by its mean and standard deviation) for calibrated ${ }^{14} \mathrm{C}$ ages of lake highstands, mainly from the central Great Basin, from Munroe and Laabs (2013) and calculated ELA's (THAR method) for cosmogenically dated moraines in the Ruby Mountains, from Laabs et al. (2013), with the scale on the right. 
where $\mathrm{Z}_{\text {toe }}$ ad $\mathrm{Z}_{\text {headwall }}$ are the reconstructed elevations of the glacier terminus and headwall top, respectively, and $\mathrm{C}_{\mathrm{THAR}}$ is an empirically determined constant. Meierding (1982) fitted this coefficient using a large number of glaciers and recommended a value of 0.4 for $\mathrm{C}_{\mathrm{THAR}}$. This value was previously used for Sierra Nevada samples by Phillips (2016). For Tioga-maximum age samples it yields a calculated ELA of 2500 to $2700 \mathrm{~m}$. This ELA range is not consistent with the results of numerical modeling of paleoglaciers in the Sierra Nevada, which resulted in ELA estimates of 3100 to $3300 \mathrm{~m}$ (Plummer and Phillips, 2003; Kessler et al., 2006). These estimates are not unique because the modeled ELA depends on a combination of assumed paleotemperature and paleoprecipitation, as well as other variables to a lesser extent. The modeled ELA's would be consistent with a value for $\mathrm{C}_{\mathrm{THAR}}$ of about 0.7 . However, I note that small, isolated drainage basins on the western fringes of the Sierra glaciated area (some of which provided radiocarbon age controls used in this paper) have mapped glacial deposits even though their maximum elevations are less than $3100 \mathrm{~m}$ (Bateman, 1965a; Bateman and Wones, 1972). These basins are not characterized by precipitous cirques that might provide anomalously large topographic shading that could result in glacier formation well below the regional ELA. I have retained the value of 0.4 for $\mathrm{C}_{\mathrm{THAR}}$ because it provides an ELA that is consistent for both these small, low-elevation glaciers and for the major, range-scale ones. However, the ELA values are intended only to provide a consistent basis of comparison for the extent of glaciation at the points where chronological control is available, rather than definitive estimates, and readers should be aware that additional modeling and field studies could justify revising them upward.

\subsection{Results}

Phillips et al. (1996) synthesized ${ }^{36} \mathrm{Cl}$ surface-exposure ages for glacial deposits from four drainages in the eastern Sierra region to identify four advances during the latter portion of the last glacial cycle. The results cited below have been increased by $7 \%$ from the original values in Phillips et al. (1996) to account for changes in production rate and models since 1996. The Tioga 1 and 2 advances at 33 and $27 \mathrm{ka}$, respectively, were in general less extensive than the subsequent Tioga 3 advance and were only found where unusual circumstances permitted their preservation. The Tioga 3 advance was found in all of the drainages studied by Phillips et al. (1996), and also those sampled in the similar subsequent study by Rood et al. (2011). Where dating is available, it consistently appears to represent the maximum glacial advance during Marine Isotope Stage (MIS) 2. The oldest Tioga 3 cosmogenic surface-exposure ages in Figure 4(a) are about $21 \mathrm{ka}$. The oldest calibrated ${ }^{14} \mathrm{C}$ ages are about $19 \mathrm{ka}$. The youngest Tioga 3 ages for both cosmogenic nuclides and ${ }^{14} \mathrm{C}$ are $18 \mathrm{ka}$, except for two ${ }^{10} \mathrm{Be}$ outliers. It is logical that the oldest cosmogenic ages would predate the ${ }^{14} \mathrm{C}$ ones because the ${ }^{14} \mathrm{C}$ ages are from organic material in lake cores overlying terminal Tioga outwash. Outwash sediments representing the early stages of the Tioga 3 advance are presumably buried well below the final outwash. The ${ }^{14} \mathrm{C}$-dated glacier positions and San Joaquin ELA's are 100 to $200 \mathrm{~m}$ lower than those from the cosmogenic-dated glacier positions. This is presumably because the cosmogenic ones are all from the east slope of the Sierra Nevada and the others from the west slope. The west side had 


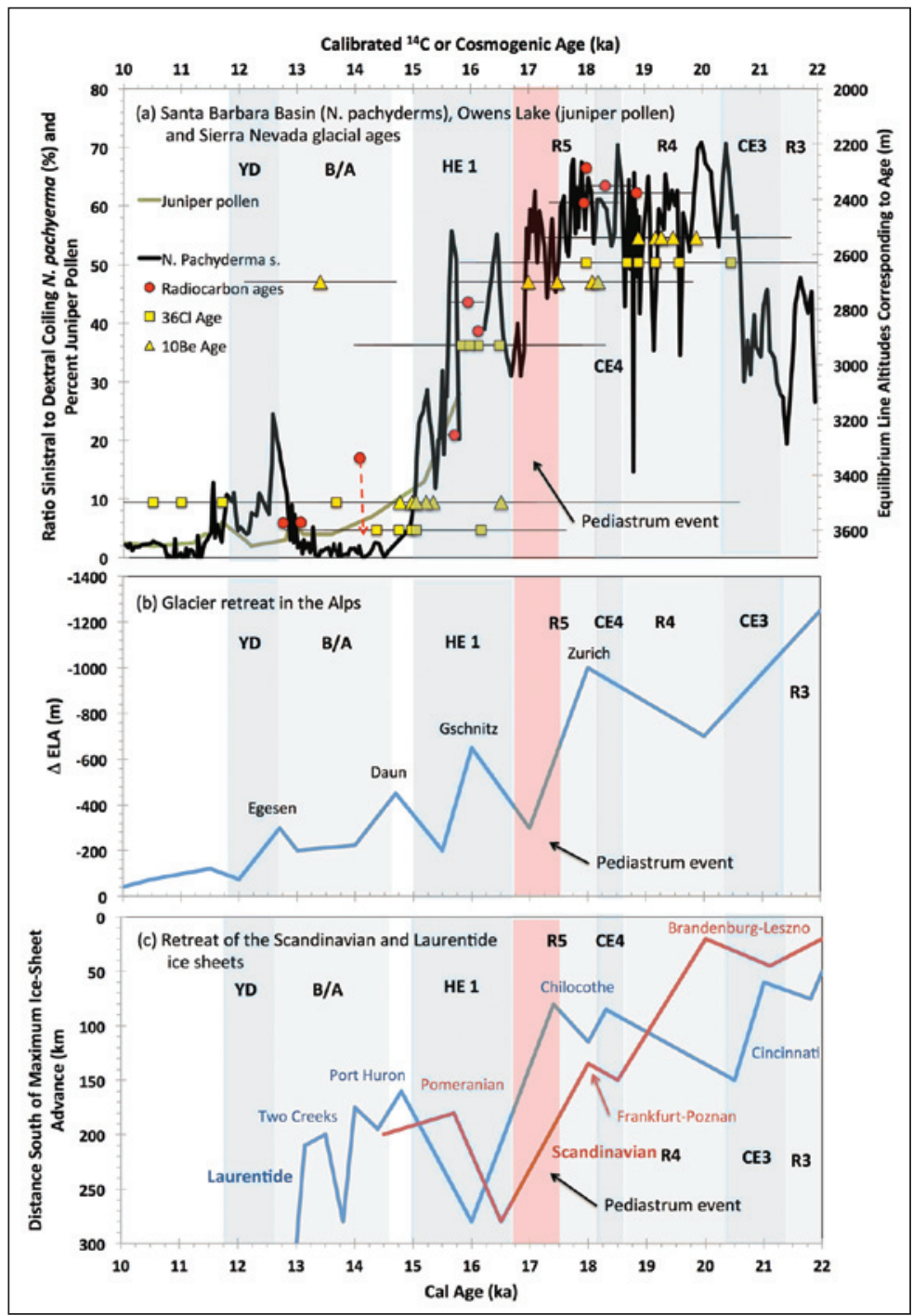

Figure 4. Comparison of the history of glacial advances in the Sierra Nevada with glacier and ice-sheet records from Europe and the Midwestern United States. (a) Same as Fig. 3(a) except that western European climate designations are indicated by the colored vertical bars. ' $R$ ' events, in pink, are episodes of extensive melting of the European Ice Sheet, as reconstructed by Toucanne et al. (2015). 'CE' designates 'cold events' in which melting was reduced. The deep pink bar is a time interval in which the freshwater alge pediastrum is abundant in nearshore marine cores off of western Europe; pediastrum presumably grew in proglacial and supraglacial lakes and was carried offshore by meltwater. It is indicative of especially vigorous melting of the ice sheet (Zaragosi et al., 2001; Toucanne et al., 2015). HE 1 is Heinrich Event 1, B/A is the $B \phi l l i n g / A l l e r \phi d$, and YD is the Younger Dryas. (b) Reconstruction of ELA reduction in the Alps, based on Ivy-Ochs (2015). (c) Retreat of the Scandinavian Ice Sheet and the Laurentide Ice Sheet from their southern maximum extent, as reconstructed by Toucanne et al. (2015), based on synthesis of previous studies. 
lower ELA's because of the decrease in precipitation eastward across the crest of the range (Kessler et al., 2006). These results appear to firmly constrain the maximal LGM glacier advances in the Sierra Nevada to the period 21-18 ka.

The ${ }^{14} \mathrm{C}$ and cosmogenic ages also agree well for the Tioga 4 moraines, with all falling in the interval 16.7 to $15.8 \mathrm{ka}$. Between 16.7 and $18 \mathrm{ka}$ there is a gap, containing only two anomalously young ${ }^{10} \mathrm{Be}$ ages from the Tioga 3 Lundy outwash site (Rood et al., 2011). The calculated ELA's for the Tioga 4 features are about $400 \mathrm{~m}$ higher than for the Tioga 3 features. In locations where moraine preservation is exceptionally good, such as Tioga Creek, Grant Lake, and June Lake (Putnam, 1950), Convict Creek (Sharp, 1969), and, to a lesser extent, Bishop Creek (Phillips et al., 2009), nested sets of recessional moraines are found immediately upstream of the Tioga 3 terminal moraine. At Tioga Creek there are 29 individual recessional moraines arranged in four clusters. The recessionals become more widely space up canyon and eventually die out well short of the Tioga 4 moraines. This pattern gives the impression of an initially gradual withdrawal from the Tioga 3 maximum that eventually accelerated into a continuous and rapid retreat.

Tioga 4 moraines are preserved in only approximately $50 \%$ of the canyons on the eastern side of the Sierra Nevada. Where they are preserved they typically take the form of a set of singular lateral moraines nested within the Tioga 3 crests that abruptly plunge to the valley bottom and loop across it, forming a single well-defined terminal loop. There are few or no recessional moraines behind the Tioga 4 crests, but high up in the range, close to the range crest, a few small recessionals have been mapped (e.g., Birman's 'Hilgard' moraines). This morphological pattern for the Tioga 4 moraines gives the strong impression of a true readvance rather than a pause in retreat, although this is difficult to prove. The most plausible scenario would seem to be that the Sierra glaciers began to retreat slowly from the Tioga maximum at about $18 \mathrm{ka}$. This retreat accelerated until the glaciers retreated past the current Tioga 4 positions around $17 \mathrm{ka}$. Between 17.0 and $16.5 \mathrm{ka}$ the climate forcing reversed and the glaciers rapidly advanced to the Tioga 4 positions, reaching maximum extent at about $16.2 \mathrm{ka}$. The climate oscillation seems to have reversed as suddenly as it appeared and the glaciers retreated rapidly toward the crest. Clark (1976) adduced geomorphic evidence for very rapid retreat of the Tioga 4 glaciers. This was supported by cosmogenic dating by James et al. (2002), who documented rapid downwasting of the Tioga 4 glacier in the South Fork of the Yuba River, and Phillips et al. (2009), who cosmogenically dated erratic boulders in a transect from the Tioga 4 terminal moraine at Bishop Creek to the range crest, with almost indistinguishable age differences resulting. Phillips et al. (2009) estimated that full deglaciation took between 500 and 1000 years. The range was thus probably virtually ice free by $15.5 \mathrm{ka}$, much earlier than the 10,000 to 11,000 year B.P. estimates of mid-tolate $20^{\text {th }}$ Century geologists (Adam, 1967; Anderson, 1987).

Between the Tioga 4 retreat and Recess Peak advance there is a complete hiatus. Recess Peak moraines are deposited directly on top of bedrock bearing $~ 15.5 \mathrm{ka}$ Tioga 4 deglacial ages (Nishiizumi et al., 1989; Phillips et al., 2009; Phillips, 2016). The Recess Peak is evidenced by diminutive moraines that are literally in the shadow of the Sierra crest. The largest glaciers were only about $4 \mathrm{~km}$ long and had ELA's only about 
$500 \mathrm{~m}$ lower than the crest. The ELA's of the Tioga 3 glaciers, for comparison, were about $2 \mathrm{~km}$ lower than the crest. The event clearly took place very close to the terminal Pleistocene (i.e., between 14 and $12 \mathrm{ka}$ ), but the amount of chronological control is small and not conclusive. The best evidence comes from three ${ }^{14} \mathrm{C}$ ages from bulk lacustrine sediment that bracket coarser Recess Peak outwash. These agree well and constrain the Recess Peak to between 14 and 13 ka (Clark and Gillespie, 1997; Clark et al., 2003). The available cosmogenic dates do not rule out this age range, but they tend to cluster in the age range of 12.7 to $11.3 \mathrm{ka}$ (Phillips et al., 2016b). The cosmogenic ages are consistent with the Recess Peak advance occurring during the Younger Dryas stade, for which there is considerable evidence of a cooling in the vicinity of the Sierra Nevada (Phillips, 2016). The ${ }^{14} \mathrm{C}$ data would force the Recess Peak to be in the millennium prior to the Younger Dryas, which most regional and global paleoclimate proxies indicate was relatively warm. Phillips (2016) has discussed the specifics of this issue at length, without being able to arrive at any secure resolution. At present, the most that can be said is that the Recess Peak moraines were in all likelihood deposited in the interval 14 to $12 \mathrm{ka}$. Following the Recess Peak there are no dated glacial deposits until the initiation of Neoglaciation (Matthes moraines) at about $3 \mathrm{ka}$. These glaciers, restricted to heavily shadowed cirque basins, reached their maximum extent during the Little Ice Age (Clark and Gillespie, 1997; Bowerman and Clark, 2011).

\subsection{Discussion}

The available data are sufficient to allow a fairly confident reconstruction of the variations in glacial extent in the Sierra Nevada from the Last Glacial Maximum to the Holocene. These fluctuations were a result of changes in climatic forcing. The principal forcings were changes in temperature and precipitation, with secondary influences from factors such as cloudiness and wind. The distribution of these factors around the seasonal cycle was also important. Several hypotheses have been advanced to explain the patterns observed in various geological proxies (e.g., glacial extent, lake levels, pollen, stable isotopes in speleothems) in the western United States. One hypothesis has invoked southward, and later return northward, migration of the jet stream under the influence of growth and shrinkage in the Laurentide/Cordilleran ice sheets (Benson and Thompson, 1987; COHMAP Members, 1988). Another has proposed that wet events within the deglacial interval were the result of incursions of moist tropical air during spring and summer (Wells, 1979; Lyle et al., 2012). A third has emphasized the role of teleconnections between oceanographic properties in the North Atlantic and the southwestern U.S. (Phillips et al., 1994; Phillips et al., 1996; Benson et al., 1997; Broecker and Putnam, 2012). Comparison of the glacial record of the Sierra Nevada with regional and global paleoclimate records can help to discriminate between these hypotheses.

\subsubsection{Comparisons with regional paleoclimate records}

In Figure 3 the reconstructed Sierra Nevada glacial chronology record is compared to various paleoclimate proxy records from the western United States. Presumably these records should all be responding to the same climate forcings, or at least closely related 
ones. Lake records provide a particularly interesting comparison. Fluctuations in both closed-basin lakes and glaciers are driven by changes in the water balance. An increase in the water balance, driven by either an increase in precipitation or a reduction in evapotranspiration/melting due to reduction in temperature, will cause both lake surface area and glacier length to increase. However, they differ in that lakes respond more strongly to changes in precipitation (Phillips et al., 1992) and glaciers to changes in temperature (Kessler et al., 2006).

The most informative comparative record is from Ocean Drilling Project (ODP) core 893A in the Santa Barbara Basin (Fig. 1). The black line in Figure 3(a) illustrates the percentage of sinistral coiling Neogloboquadrina pachyderma, a planktonic foraminifera, with data from Hendy et al. (2002), but replotted on the revised timescale of Kennett et al. (2008). The percentage of sinistral coiling $N$. pachyderma increases as temperature decreases. Since the percent sinistral coiling is plotted increasing upward, this corresponds to temperature decreasing upward. This record shows a rather remarkable correspondence with the record of Sierra Nevada glacial ELA's on the same graph. The coldest temperatures in the Santa Barbara Basin record began at $21 \mathrm{ka}$ and continued through $18 \mathrm{ka}$, exactly the period of the Tioga 3 maximum glacial extent. After $18 \mathrm{ka}$ the temperature decreased slowly at first, then more rapidly, in a fashion similar to the pattern of glacial retreat inferred from the recessional moraines at Lee Vining Creek and other sites discussed above. At $16.4 \mathrm{ka}$ the temperature reversed and stayed colder until $15.7 \mathrm{ka}$, coinciding with the ages for the Tioga 4 readvance. At $15.7 \mathrm{ka}$ there was very rapid warming, with a minor cold oscillation at $\sim 15.0 \mathrm{ka}$. The careful glacial geology mapping by Birman (1964) revealed a set of small moraines high in the Sierra Nevada that he termed 'Hilgard'. He considered these to be Holocene, but they are generally now regarded as latest Tioga (Gillespie and Clark, 2011) and they may well correspond to this small cold oscillation. Following the oscillation, temperatures remained warm until $\sim 12.7 \mathrm{ka}$, which approximately corresponds to the dates for the Recess Peak advance. It thus appears that the Santa Barbara Basin N. pachyderma provides a continuous temperature proxy that offers context for the discontinuous record of glacial advances.

The site of ODP 893A is $350 \mathrm{~km}$ southwest of the area shown in Figure 2. It may seem surprising that paleotemperatures there should covary so strongly with those in the south and central Sierra Nevada, but this is consistent with regional climatology. The largest storms hitting the central Sierra cross the coastline in precisely this area and move northeastward across the Sierra Nevada (Pandey et al., 1999).

There are some minor discrepancies between the two records. The direct dating from the Sierra Nevada indicates that the Tioga 4 advance culminated and retreated rapidly at $16.2 \mathrm{ka}$ but the $N$. pachyderma indicates closer to $15.7 \mathrm{ka}$ for this event. The Sierra ${ }^{14} \mathrm{C}$ dating places the Recess Peak advance between 14 and 13 ka whereas the $N$. pachyderma puts it between 13 and $12.3 \mathrm{ka}$. This range is clearly within the Younger Dryas stade while the direct dating puts it just before the Younger Dryas. These differences are too small to resolve without further research. I have preferred the direct age controls in the Sierra Nevada for this paper. 
Figure 3(a) also includes a curve of percent juniper pollen from Owens Lake cores from Mensing (2001). Juniper is considered to be an indicator of cold temperature in this setting. This curve closely mimics that from the Santa Barbara Basin, supporting substantial glacial withdrawal by $15.5 \mathrm{ka}$.

Figures 3(b) and 3(c) illustrate lake-level reconstructions from the Owens River system (Phillips, 2008) and Lake Lahontan (Reheis et al., 2014). The southern portion of the area for which moraine dates are given in Figure 3(a) drained into the Owens system while the northern portion drained into Lake Lahontan, thus it is reasonable to seek similarities in these records. Broadly speaking, they are indeed similar, with relatively high lake positions in the 21 to $19 \mathrm{ka}$ interval, corresponding to the Tioga 3 advance, a drop in lake level around $18 \mathrm{ka}$, corresponding to Tioga 3 retreat, and an abrupt lake rise around $16 \mathrm{ka}$, corresponding to the Tioga 4 readvance. The Lahontan record differs from the Sierra glacial one in having the highstand correlative with Tioga 3 be less pronounced that that correlative with Tioga 4. The logical inference is that the LGM period (Tioga 3) was colder and drier than the climate at the time of the Tioga 4 readvance. The Owens record reverses this relationship. The chronology of the Owens system has been less studied than that of Lahontan and is inherently difficult to determine because of the lack of suitable materials for dating and methodological problems such as radiocarbon reservoir effects in the closed-basin lakes and variable initial isotope ratios for the U/Th dating methods, thus it is possible that this discrepancy is an artifact. On the other hand, it may reflect actual variations in the climate processes with latitude.

Figure 3(d) shows the summed probability densities for calibrated ${ }^{14} \mathrm{C}$ ages from closed-basin lake highstands in the southwestern United States, from Munroe and Laabs (2013), and calculated ELA's corresponding to cosmogenic dates for terminal moraines in the Ruby Mountains of Nevada from Laabs et al. (2013). These are roughly $400 \mathrm{~km}$ northeast of the Sierra Nevada. The lake record is similar to Lake Lahontan in showing a cluster of highstands at 20 to $18 \mathrm{ka}$, a decrease at $18 \mathrm{ka}$, followed by a dramatic peak at $16.6 \mathrm{ka}$. The glacier ages also yield a pattern similar to the Sierra Nevada, with maximum glacial extents at $20.5 \mathrm{ka}$, retreat, and a readvance or stillstand at 17 to $16 \mathrm{ka}$, followed by retreat. These patterns support the model of very cold but relatively dry conditions during the LGM, followed by warming, with a brief pulse of somewhat colder and much wetter climate between 17 and $16 \mathrm{ka}$.

The general patterns in all of these records are quite similar, but there are discrepancies. One has to do with the ending of the LGM cold/dry period. In the Sierra glacial record, the Owens lacustrine one and the lacustrine compendium this happens at about $18 \mathrm{ka}$, but in the Lahontan one it is earlier, at 20 to $19 \mathrm{ka}$. Another is the timing of the cool/wet pulse during Tioga 4. The glacial record indicates it was at about $16.2 \mathrm{ka}$, but the compendium would place it at $16.8 \mathrm{ka}$ and the Lahontan one at 16.0 to $15.7 \mathrm{ka}$. These differences are marginal in terms of realistic dating precision and accuracy and may be artifacts in dating, but they may also reflect differences in the response times of the various hydrological systems to essentially synchronous climate impulses, or they may reflect geographic differences in the timing of the climate impulses. Further research is required before these questions can be resolved with confidence. 
The timing of the Sierra Nevada retreat and advance to the Tioga 4 limit, and the associated lacustrine fluctuations, is quite similar to that of Broecker's 'Big Dry' and 'Big Wet' events in the Southwest (Broecker et al., 2009; Broecker and Putnam, 2012). However, the time intervals are somewhat more restricted. Although Sierra Nevada glaciers began to retreat at $\sim 18 \mathrm{ka}$, similar to the beginning of the 'Big Dry', this was gradual and rapid retreat did not begin until about $17 \mathrm{ka}$. Broecker places the wet and cold reversal corresponding to the start of the 'Big Wet' at about $16.2 \mathrm{ka}$, about 500 years later than the initiation of the Tioga 4 advance. Finally, the Tioga 4/Lahontan highstand event ended at $16.0 \mathrm{ka}$ or slightly thereafter and the shrinkage of both glaciers and lakes was rapid. This is about 1500 years earlier than Broecker's date. As I discuss below, the differences in chronology suggest global climatic forcings somewhat different than those Broecker identified.

Probably the single most important correlation to come out of this comparison is the very close correspondence of the Tioga 4 readvance in the Sierra Nevada with the highstand in pluvial Lake Lahontan, which is very securely dated (Adams and Wesnousky, 1998). They were clearly both responses to a relatively brief (1 to $2 \mathrm{kyr}$ ) pulse of very wet and cold, but not extremely cold, climate. Refinement of the chronologies and modeling of the lacustrine and glacial systems should help to improve our understanding of this brief but potent climate oscillation.

\subsubsection{Comparisons with distant paleoclimate records}

In Figure 4 the deglaciation record from the Sierra Nevada is compared with glacial records from Europe and the Midwestern United States. The background patterns are derived from a chronology of the retreat of the European Ice Sheet (EIS) based on interpretation of neodymium isotopes and a wide range of other provenance and paleoclimate indicators in cores from the Bay of Biscay, by Toucanne et al. (2015). The vertical pink bars labeled " $R$ " are 'runoff events' in the 'Channel river' that flowed in the present position of the English Channel and drained nearly all of the southern margin of the European Ice Sheet. Toucanne et al. (2015) interpreted these events as the result of melting and retreat of the southern margin of the ice sheet. The darker pink bar labeled "pediastrum event" shows the timing of the deposition of large numbers of pediastrum, a freshwater algae that presumably grew in proglacial and supraglacial lakes and indicates especially rapid and voluminous melting of the ice sheet (Zaragosi et al., 2001). The blue bars labeled "CE" stand for 'cold events' that intervened between the runoff events (the CE terminology originates with this paper). HE 1 stands for 'Heinrich event 1', within which greatly enhanced deposition of ice rafted debris particles indicates very large numbers of icebergs off the shore of western Europe. B/A is the Bølling/Ållerød warm event and YD the Younger Dryas episode of cold temperature and ice advance at the termination of the last glaciation.

The post-LGM history of the Sierra Nevada glaciers, along with the closely related Santa Barbara Basin paleotemperature record, shows a close correspondence with the European ice-sheet fluctuations. Hendy et al. (2002) previously noted this correspondence. The Cold Event 3 corresponds to a strong cooling in the Santa Barbara Basin and to the Tioga 3 advance in the Sierra. This culminateed in the maximum Tioga 
3 advance during the following Cold Event 4. R5 was the strongest of the Runoff Events and during it the Tioga glaciers shrank to half, or less, of their Tioga 3 maximum lengths. The Santa Barbara Basin paleotemperature proxy appears to show significantly greater warming during the 'pediastrum event' in the second half of R5 than during the first half. The transition from R5 to Heinrich Event 1 was marked by rapid cooling in the Santa Barbara Basin and in the Sierra, the Tioga 4 advance. The California records, however, at this time began to differ from the European Ice Sheet melting chronology in that the Santa Barbara Basin temperature warmed and the Tioga 4 glaciers precipitously retreated about two-thirds of the way through HE 1, rather than at the end of it. The Bølling/Ållerød warming, which was pronounced in northern Europe, was not reflected in the California records, which had already reached near-Holocene values. It is noteworthy that the final collapse of the Sierra Nevada glacier complex predated the Bølling/Ållerød warming by more than 1000 years. As discussed above, whether the Younger Dryas corresponded to cooling and glacier advance in California is debatable due to chronological uncertainties. The Santa Barbara Basin N. pachyderma record places a marked cooling event at the very beginning of the Younger Dryas, whereas the direct radiocarbon dates from Sierra Nevada lakes would place the Recess Peak advance a few hundred years earlier, during the latest Bølling/Ållerød.

In Figure 4(b) and 4(c) I compare the Sierra Nevada record to the similar record from the Alps, based on Ivy-Ochs (2015), and to the margins of the Scandinavian Ice Sheet and the Laurentide Ice Sheet, from Toucanne et al. (2015) based on synthesis of earlier studies. The pattern of glacial retreat from the Alps is remarkably similar to that of the Sierra Nevada. Notably, the most prominent post-LGM advances in both ranges, the Tioga 4 in the Sierra Nevada and the Gschnitz in the Alps, both began rapid retreat at $\sim 16 \mathrm{ka}$, which is in the middle of H1. The only substantive difference is that there is no obvious Sierra equivalent to the Daun advance at $\sim 14.7 \mathrm{ka}$. There is a brief temperature reversal in the Santa Barbara Basin proxy record at $\sim 15.2 \mathrm{ka}$ that might correspond if there are significant chronology biases in one record or the other. The two continental ice sheets show generally similar patterns to the Sierra Nevada and Alps, but appear to be lagged by 1000 to 1500 years. This can likely be attributed to the much longer response times of continental ice sheets than mountain glaciers.

One explanation for the back-and-forth of long warm periods of melting around the North Atlantic interspersed with more brief cold episodes in which glaciers and ice sheets advanced (e.g., Denton et al., 2010; Toucanne et al., 2015) is that the initiation of melting was a long-term response to rising Northern Hemisphere insolation and global $\mathrm{CO}_{2}$ concentration (Shakun et al., 2015). This released a blanket of light fresh water that tended to suppress the strength of the Atlantic Meridianal Overturning Circulation (AMOC) that advects heat into the shallow North Atlantic Ocean. Suppression of the AMOC caused very cold winters. Summers, however, remained reasonably warm due to the increase in insolation, permitting ongoing melting. The subtropical Atlantic began to warm due to suppression of the AMOC, eventually diffusing north and warming the North Atlantic at the depth of the base of the ice shelves fringing the continental ice sheets. This destabilized the ice shelves and ice streams from the ice sheets then flooded the North Atlantic with icebergs. The southward spread of icebergs and consequent light 
meltwater produced very extensive and thick sea ice that persisted late into the spring and summer, creating cold summers as well as winters and permitting the glaciers and ice sheets to advance. This cyclic behavior intensified through the period after $20 \mathrm{ka}$, ultimately culminating in the immense iceberg event known as Heinrich 1.

This model can readily explain the pattern of glacial retreat and advance in the Alps, which are directly affected by weather originating in the North Atlantic. The Sierra Nevada, however, is quite distant from the North Atlantic and, due to the predominant eastward atmospheric circulation there, is dominated by weather originating in the eastern Pacific Ocean. Thus some non-obvious teleconnection is needed to link the glacial patterns in these two areas. The most plausible one would appear to be the extent and persistence of sea ice. Chiang and Bitz (2005) and Chiang et al. (2014) have modeled global teleconnections consistent with the connection between the North Atlantic and the Sierra Nevada. In their modeling these teleconnections are driven by the same fluctuations in sea ice that could have more directly influenced Alpine glacial advances and retreats. Of all of the large number of North Atlantic paleoceanographic records assembled by Toucanne et al. (2015), the one most clearly correlative with the Tioga 4 advance in the Sierra Nevada (and also the Gschnitz advance in the Alps) is the percent abundance of the polar dinocyst Islandium minutum, which is taken to indicate sea-ice cover persisting more than six months of the year, as observed in Core MD95-2002, located west of Brittany and south of Ireland. The concentration of this dinocyst rose abruptly at $16.7 \mathrm{ka}$ and oscillated through three maxima, the last of which falls sharply at $15.9 \mathrm{ka}$. This pattern, in turn, is closely related to Heinrich Event 1 . Ice rafted debris in the same core begins to increase at about $17 \mathrm{ka}$, but increases gradually until a sharp increase at $16.0 \mathrm{ka}$. Subsequent to this it generally follows the same pattern as I. minutum, then decreases steadily through the second half of $\mathrm{H} 1$. This suggests that, although icebergs continued to be exported to the Atlantic margin of Europe throughout H1, conditions were highly favorable to sea-ice formation only during the first half. This was most likely due to continued influx of residual meltwater from the R5 event, and particularly from the intense 'pediastrum event' in its second half, that supplemented melting icebergs to supply a thick freshwater cap on the Atlantic west of northern Europe. As this influx of glacial meltwater diminished due to increasingly cold summers, the production of sea ice may have waned even though icebergs continued to invade.

\subsection{Conclusions}

The history of the advances and retreats of the glacial complex covering the higher portion of the Sierra Nevada of California can be established with a reasonable degree of certainty by compiling results from numerous studies employing ${ }^{14} \mathrm{C}$ and cosmogenic dating. It is also aided by a nearly continuous record of relative paleotemperature obtained from the percentage of sinistral coiling N. pachyderma from the Santa Barbara Basin $350 \mathrm{~km}$ southwest of the Sierra Nevada, which shows a rather remarkable correspondence with the glacial record.

The combined records indicate that the Sierra Nevada glaciers expanded to their maximum LGM extent (Tioga 3 glaciation) between 22 and $21 \mathrm{ka}$. They then maintained 
a fairly constant length until $18 \mathrm{ka}$, forming the impressive Tioga terminal and lateral moraines observed in the mouths of many valleys of the range. At $18 \mathrm{ka}$ they began to slowly retreat. A gradual retreat of mountain glaciers has been observed worldwide at about this time (Schaefer et al., 2006) and can be linked to increasing Northern Hemisphere summer insolation, and thus temperature, and increasing atmospheric $\mathrm{CO}_{2}$ (Shakun et al., 2015). The termination of this period of slow retreat has not been directly dated, but the Santa Barbara Basin core suggests that it was correlative with rapid warming at ca. $17 \mathrm{ka}$. The glaciers retreated substantially at this time, although exactly how far is not presently known.

At about $16.7 \mathrm{ka}$ the glaciers began to readvance and occupied their maximum Tioga 4 positions at about $16.2 \mathrm{ka}$. These positions represented only about two-thirds of the Tioga 3 ELA reduction. After about $16.2 \mathrm{ka}$ the Tioga 4 glaciers retreated very rapidly and had melted back to the crest of the range by 15.7 to $15.5 \mathrm{ka}$. This complete loss of the Sierra Nevada glacial complex was at least 1000 years prior to the Bølling warming in Europe. There is no record of subsequent glacial expansion until the Recess Peak advance. Dating for this event is conflicting, but it certainly happened between 14 and $12 \mathrm{ka}$. A limited amount of direct ${ }^{14} \mathrm{C}$ dating supports an age between 14.0 and 13.0 $\mathrm{ka}$, but correlation with the Santa Barbara core and other local paleoclimate proxies is more consistent with between 13.0 and $12.5 \mathrm{ka}$, during the early part of the Younger Dryas stade. The extent of the Recess Peak advance was minor, with an ELA reduction of about $100 \mathrm{~m}$, compared to $>1200 \mathrm{~m}$ for the Tioga 3. The Recess Peak advance was very brief and the glaciers retreated rapidly to positions that were probably less extensive than historical glaciers in the range.

Comparison of the Sierra Nevada glacial chronology with regional paleoclimate records indicates that glacial advances were correlative with highstands in the closedbasin lakes in the Great Basin to the east. The Owens River system that drains the eastern slopes of the southern Sierra Nevada appears to show higher lake levels during the Tioga 3 period than Tioga 4, whereas Lake Lahontan, draining the central Sierra Nevada, shows the reverse pattern. The Owens system has been much less studied and this may be an artifact, but alternatively it may reflect the latitudinal position of maximum precipitation at different periods. All of the lakes show a period of low-to-very-low lake levels that approximately correspond with the period of glacial retreat between Tioga 3 and Tioga 4. The all-time highstand of Lake Lahontan at $\sim 16$ ka clearly coincides very closely with the Tioga 4 maximum advance. Following this highstand the lakes give evidence of rapid fall, just as the Tioga 4 glaciers retreated rapidly. The lakes also show a subsequent minor rise that probably coincided with the Recess Peak minor advance.

Comparison of the Sierra Nevada glacial chronology with glacial records from western Europe and the Midwestern United States also show close correspondences. In general, Sierra Nevada glaciers advanced during cold episodes when the European Ice Sheet and Alpine glaciers also advanced, and retreated during periods when large amounts of meltwater were generated by the European Ice Sheet. One particularly intriguing correspondence is that the episode of rapid Tioga 3 retreat at about $17 \mathrm{ka}$, and a period of pronounced fall in Great Basin lake levels, seems to correlate with 
the particularly intense 'pediastrum' meltwater event. The following Tioga 4 advance apparently coincided with the beginning of the Heinrich 1 iceberg release event. It also coincided with the maximal Great Basin pluvial lake highstands. However, neither the Tioga 4 advance nor the pluvial highstands persisted through the Heinrich 1 event. Instead they both declined rapidly about half way through Heinrich 1 . The timing of the advance and reversal appears to correlate most strongly with the abundance of $I$. minutum, a dinocyst indicating persistent sea-ice cover, off the shores of Europe. This observation supports prior modeling studies indicating that climate events in the North Atlantic and western North America may be linked by atmospheric teleconnections that are in considerable part driven by the extent and persistence of sea ice in the North Atlantic.

The chronology and correlations described above enable an evaluation of the three hypotheses proposed to explain the paleohydrologic history of the Great Basin during the deglacial period, that were described under Discussion. The first was that growth and shrinkage of Great Basin glaciers and lakes could be explained by southward, and return northward, migration of the jet stream under the influence of growth and shrinkage in the Laurentide/Cordilleran ice sheets (Benson and Thompson, 1987; COHMAP Members, 1988). Although it seems quite plausible that shifts in the position of the jet stream influenced the geographical distribution of precipitation, the reconstructed history of Sierra Nevada glaciation is not compatible with this hypothesis because it shows rapid transitions between cold/wet and warm/dry states whereas the ice-sheet dimensions varied slowly and fairly monotonically (Ullman et al., 2015).

The second hypothesis was that wet events were the result of incursions of moist tropical air during spring and summer within the deglacial interval (Wells, 1979; Lyle et al., 2012). Lyle et al. (2012) in particular associate the highstands of Lakes Lahontan and other Great Basin lakes at $\sim 16$ ka with a warm, tropical, summer moisture source, based in large part on the observation that paleoclimatic evidence indicates the climate of coastal California was relatively dry during this time down to about $35^{\circ} \mathrm{N}$ latitude, which is well south of the Sierra Nevada and Lake Lahonton. However, the synchroneity of the Tioga 4 glacial advance with the Lahontan highstand argues strongly against this hypothesis. Large amounts of warm summer precipitation would have had a strongly negative effect on glacial mass balance and presumably resulted in glacial retreat. Instead, the Tioga 4 glaciers advanced vigorously and reached an ELA reduction that was about two-thirds that of the maximum reduction of the last glacial cycle. This is a response that is much more compatible with increased winter precipitation than summer precipitation. The dryness along the northern California coast is not necessarily incompatible with Sierra Nevada wetness. At the present time large winter storms impact the central Sierra Nevada from the southwest (Pandey et al., 1999), crossing the coastline approximately at the Santa Barbara Basin. As described above, the correspondence between the Sierra glacial chronology and the paleotemperature record from $N$. pachyderma in ODP Core $893 \mathrm{~A}$ is very strong. The time of the Tioga 4 advance was one of increased percentage of sinistral $N$. pachyderma, indicating cooler temperature rather than warmer. Furthermore, pollen counts from Core 893A indicate that the largest peak of precipitation for the entire $80 \mathrm{ka}$ pollen record was at $16 \mathrm{ka}$ 
(Lyle et al., 2012). Thus, both the Tioga 4 advance and the expansion of Lake Lahontan at about $16 \mathrm{ka}$ are more likely to have been the result of cooler temperatures and greatly enhanced winter precipitation flowing northeast from the area of the Santa Barbara Basin than they are to have been the result of enhanced warm summer precipitation.

The third hypothesis emphasized the role of teleconnections between oceanographic properties in the North Atlantic and the southwestern U.S. (Phillips et al., 1994, 1996; Benson et al., 1997; Broecker and Putnam, 2012). As described above, the similarities between the deglacial chronologies in northern Europe, particularly the Alps, and the Sierra Nevada is striking. This supports the existence of some kind of teleconnection. The teleconnection has been hypothesized to be modulated through latitudinal shifts in the position of the Inter-Tropical Convergence Zone (ITCZ), which in turn produces shifts in the jet streams. The principal factor responsible for the North Atlantic/ITCZ connection may be the extent and duration of sea-ice cover in the southern part of the North Atlantic (Chiang and Bitz, 2005; Broecker and Putnam, 2012). Specific paleoceanographic indicators of greater and lesser sea-ice extent near the southern margin of the European Ice Sheet seem to show a close correspondence to the timing of retreat and advance of the Sierra Nevada glaciers, supporting this hypothesis.

\section{References}

Adam, D.P. 1967. Late Pleistocene and recent palynology in the central Sierra Nevada, California, In: E.J. Cushing, H.E. Wright, Jr. (Eds.), Quaternary Paleocology. Yale University Press, New Haven, pp. 275-301.

Adams, K.D., Wesnousky, S.G. 1998. Shoreline processes and the age of the Lake Lahontan highstand in the Jessup embayment, Nevada. Geological Society of America Bulletin 110, 1318-1332.

Anderson, R.S. 1987. Late-Quaternary environments of the Sierra Nevada. Ph.D. Dissertation, University of Arizona, Tucson, 290 pp.

Bacon, S.N., Burke, R.M., Pezzopane, S.K., Jayko, A.S. 2006. Last glacial maximum and Holocene lake levels of Owens Lake, eastern California, USA. Quaternary Science Reviews 25, 1264 1282. http://doi.org/10.1016/j.quascirev.2005.10.014.

Bateman, P.C. 1965a. Geologic map of the Blackcap Mountain quadrangle, Fresno County, California. U.S. Geological Survey Geologic Quadrangle Map GQ-428.

Bateman, P.C. 1965b. Geology and tungsten mineralization of the Bishop District, California. U.S. Geological Survey Professional Paper 470, p. 208 pp.

Bateman, P.C., Moore, J.G. 1965. Geologic Map of the Mount Goddard Quadrangle, Fresno and Inyo Counties, California. U.S. Geological Survey Geological Quadrangle Map 429.

Bateman, P.C., Wones, D.R. 1972. Geologic map of the Huntington Lake quadrangle, central Sierra Nevada. U.S. Geological Survey Geologic Quadrangle Map GQ-987.

Benson, L., Burdett, J., Lund, S., Kashgarian, M., Mensing, S. 1997. Nearly synchronous climate change in the Northern Hemisphere during the last glacial termination. Nature 388, 263-265.

Benson, L.V., Thompson, R.S. 1987. Lake-level variations in the Lahontan basin for the past 50,000 years. Quaternary Research 28, 69-85. http://doi.org/10.1016/0033-5894(87)90034-2.

Birman, J.H. 1964. Glacial geology across the crest of the Sierra Nevada. Geological Society of America Special Paper 75, Boulder, Colorado, 80 pp.

Blackwelder, E. 1931. Pleistocene glaciation in the Sierra Nevada and Basin ranges. Geological Society of America Bulletin 42, 865-922. 
Bowerman, N.D., Clark, D.H. 2011. Holocene glaciation of the central Sierra Nevada, California. Quaternary Science Reviews 30, 1067-1085. http://doi.org/10.1016/j.quascirev.2010.10.014.

Broecker, W., Putnam, A.E. 2012. How did the hydrologic cycle respond to the two-phase mystery interval? Quaternary Science Reviews 57, 17-25. http://doi.org/10.1016/j. quascirev.2012.09.024.

Broecker, W.S., McGee, D., Adams, K.D., Cheng, H., Edwards, R.L., Oviatt, C.G., Quade, J. 2009. A Great-Basin wide dry episode during the first half of the Mystery Interval? Quaternary Science Reviews 28, 2557-2563. http://doi.org/10.1016/j.quascirev.2009.07.007.

Charlesworth, J.K. 1957. The Quaternary Era. Arnold, London.

Chiang, J.C.H., Bitz, C.M. 2005. Influence of high latitude ice cover on the marine Intertropical Convergence Zone. Climate Dynamics 25, 477-496. http://doi.org/10.1007/s00382-0050040-5.

Chiang, J.C.H., Lee, S.-Y., Putnam, A.E., Wang, X. 2014. South Pacific Split Jet, ITCZ shifts, and atmospheric North-South linkages during abrupt climate changes of the last glacial period. Earth and Planetary Science Letters 406, 233-246. http://doi.org/10.1016/j.eps1.2014.09.012.

Clark, D., Gillespie, A.R., Clark, M., Burke, R. 2003. Mountain glaciation of the Sierra Nevada, In: D.J. Easterbrook (Ed.), Quaternary Geology of the United States, INQUA 2003 Field Guide Volume. Desert Research Institute, Reno, Nevada, pp. 287-312.

Clark, D.H., Gillespie, A.R. 1997. Timing and significance of late-glacial and Holocene cirque glaciation in the Sierra Nevada, California. Quaternary International 38-39, 21-38. http:// doi.org/10.1016/S1040-6182(96)00024-9.

Clark, M.M. 1976. Evidence for rapid destruction of latest Pleistocene glaciers of the Sierra Nevada, California. Geological Society of America Abstracts with Programs 8, 361-362.

COHMAP Members 1988. Climatic changes of the last 18,000 Years: Observations and model simulations. Science 241, 1043. http://doi.org/10.1126/science.241.4869.1043.

Denton, G.H., Anderson, R.F., Toggweiler, J.R., Edwards, R.L., Schaefer, J.M., Putnam, A.E. 2010. The Last Glacial Termination. Science 328, 1652-1656. http://doi.org/10.1126/ science. 1184119 .

Dühnforth, M., Anderson, R.S., Ward, D., Stock, G.M. 2010. Bedrock fracture control of glacial erosion processes and rates. Geology 38, 423-426. http://doi.org/10.1130/G30576.1.

Evans, J.M., Stone, J.O.H., Fifield, L.K., Cresswell, R.G. 1997. Cosmogenic chlorine-36 production in K-feldspar. Nuclear Instruments and Methods in Physics Research. Section B: Beam Ibteractions with Materials and Atoms123, 334-340. http://doi.org/10.1016/S0168$583 \mathrm{X}(96) 00714-8$.

Fullerton, D.S. 1986. Chronology and correlation of glacial deposits in the Sierra Nevada, California, In: V. Sibrava, D.Q. Bowen, G.M. Richmond (Eds.), Quaternary Glaciations in the Northern Hemisphere. Report of the International Geological Correlation Programme Project 24. Pergamon Press, Oxford, pp. 161-169.

Gillespie, A.R., Clark, D.H. 2011. Glaciations of the Sierra Nevada, California. In: J. Ehlers, P.L. Gibbard, P.D. Hughes (Eds.), Quaternary Glaciations - Extent and Chronology: A Closer Look (Developments in Quaternary Science, Vol. 15). Elsevier, Amsterdam, pp. 447-463.

Gillespie, A.R., Clark, M.M., Burke, R.M. 1999. Eliot Blackwelder and the alpine glaciations of the Sierra Nevada, In: E.M. Moores, D. Sloan, D.L. Stout (Eds.), Classic Cordilleran concepts: A View from California. Geological Society of America Special Paper 338, Boulder, pp. 443-452.

Gillespie, A.R., Zehfuss, P.H. 2004. Glaciations of the Sierra Nevada, California, USA, Quaternary Glaciations - Extent and Chronology - Part II: North America. Elsevier, pp. 51-62.

Hendy, I., Kennett, J.P., Roark, E.B., Ingram, B.L. 2002. Apparent synchroneity of submillennial scale climate events between Greenland and Santa Barbara Basin, California from 30-10 ka. Quaternary Science Reviews 21,1167-1184.http://doi.org/10.1016/S0277-3791(01)00138-X. 
Ivy-Ochs, S. 2015. Glacier variations in the European Alps at the end of the last glaciation. Cuadernos de Investigación Geográfica 41, 295-315. http://doi.org/10.18172/cig.12750.

James, L.A., Harbor, J., Fabel, D., Dahms, D., Elmore, D. 2002. Late Pleistocene glaciations in the northwestern Sierra Nevada, California. Quaternary Research 57, 409-419. http://doi. org/10.1006/qres.2002.2335.

Jayko, A.S., Forester, R.M., Yount, J.C., Kaufman, D., McGeehin, J., Phillips, F.M., Mahan, S.A. 2008. Late Pleistocene lakes and wetlands, Panamint Valley, California, In: M.C. Reheis, R. Hershler, D.M. Miller (Eds.), Late Cenozoic Drainage History of the Southwestern Great Basin and Lower Colorado River Region: Geologic and Biotic Perspectives. Geological Society of America Special Paper 439, Boulder, Colorado, pp. 151-184.

Kennett, D.J., Kennett, J.P., West, G.J., Erlandson, J.M., Johnson, J.R., Hendy, I.L., West, A., Culleton, B.J., Jones, T.L., Stafford Jr, T.W. 2008. Wildfire and abrupt ecosystem disruption on California's Northern Channel Islands at the Allerød-Younger Dryas boundary (13.0-12.9 ka). Quaternary Science Reviews 27, 2530-2545. http://doi.org/10.1016/j. quascirev.2008.09.006.

Kessler, M.A., Anderson, R.S., Stock, G.M. 2006. Modeling topographic and climatic control of east-west asymmetry in Sierra Nevada glacial length during the Last Glacial Maximum. Journal of Geophysical Research 111. http://doi.org/10.1029/2005Jf000365.

King, C. 1878. Report of the geological exploration of the Fortieth Parallel. Systematic Geology $1,459-529$.

Knopf, A. 1918. A geologic reconnaissance of the Inyo Range and the eastern slope of the Sierra Nevada, California, with a section on the stratigraphy of the Inyo Range by Edwin Kirk. $U$. S. Geological Survey Professional Paper 110, $130 \mathrm{pp}$.

Laabs, B.J.C., Munroe, J.S., Best, L.C., Caffee, M.W. 2013. Timing of the last glaciation and subsequent deglaciation in the Ruby Mountains, Great Basin, USA. Earth and Planetary Science Letters 361, 16-25. http://doi.org/10.1016/j.epsl.2012.11.018.

Lin, J.C., Broecker, W.S., Hemming, S.R., Hajdas, I., Anderson, R.F., Smith, G.I., Kelley, M., Bonani, G. 1998. A reassessment of U-Th and ${ }^{14} \mathrm{C}$ ages for late-glacial high-frequency hydrological events at Searles Lake, California. Quaternary Research 49, 11-23. http://doi. org/10.1006/qres.1997.1949.

Lyle, M., Heusser, L., Ravelo, C., Yamamoto, M., Barron, J., Diffenbaugh, N.S., Herbert, T., Andreasen, D. 2012. Out of the tropics: The Pacific, Great Basin lakes, and late Pleistocene water cycle in the western United States. Science 337, 1629-1633. http://doi.org/10.1126/science.1218390.

Marrero, S., Phillips, F.M., Borchers, B., Lifton, N., Aumer, R. 2016a. Cosmogenic nuclide systematics and the CRONUScalc program. Quaternary Geochronology 31, 160-187.

Marrero, S.M., Phillips, F.M., Caffee, M.W., Gosse, J.C. 2016b. CRONUS-Earth cosmogenic ${ }^{36} \mathrm{Cl}$ calibration. Quaternary Geochronology 31, 199-219. http://doi.org/10.1016/j. quageo.2015.10.002.

Matthes, F.E. 1929. Multiple glaciation in the Sierra Nevada. Science 70, 75-76.

Matthes, F.E. 1930. Geologic history of the Yosemite Valley. U.S. Geological Survey Professional Paper 160, 137 pp.

McPhillips, D., Brandon, M.T. 2012. Topographic evolution of the Sierra Nevada measured directly by inversion of low-temperature thermochronology. American Journal of Science 312, 90-116. http://doi.org/10.2475/02.2012.02.

Meierding, T.C. 1982. Late Pleistocene glacial equilibrium-line altitudes in the Colorado Front Range: A comparison of methods. Quaternary Research 18, 289-310. http://doi. org/10.1016/0033-5894(82)90076-X.

Mensing, S.A. 2001. Late Glacial and early Holocene vegetation and climate change near Owens Lake, eastern California. Quaternary Research 55, 57-65. http://doi.org/10.1006/ qres.2000.2196. 
Moore, J.G., Moring, B.C. 2013. Rangewide glaciation in the Sierra Nevada, California. Geosphere 9, 1804. http://doi.org/10.1130/GES00891.1.

Munroe, J.S., Laabs, B.J.C. 2013. Temporal correspondence between pluvial lake highstands in the southwestern US and Heinrich Event 1. Journal of Quaternary Science 28, 49-58.

Nishiizumi, K., Winterer, E.L., Kohl, C.P., Lal, D., Arnold, J.R., Klein, J., Middleton, R. 1989. Cosmic ray production rates of ${ }^{10} \mathrm{Be}$ and ${ }^{26} \mathrm{Al}$ in quartz from glacially polished rocks. Journal of Geophysical Research 94, 17907-17915. http://doi.org/10.1029/JB094iB12p17907.

Orme, A.R., Orme, A.J. 2008. Late Pleistocene shorelines of Owens Lake, California, and their hydroclimatic and tectonic implications. In: M.C. Reheis, R. Hershler, D.M. Miller (Eds.), Late Cenozoic Drainage History of the Southwestern Great Basin and Lower Colorado River Region: Geologic and Biotic Perspectives. Geological Society of America Special Paper 439, Boulder, Colorado, pp. 207-226.

Osborn, G., Bevis, K. 2001. Glaciation in the Great Basin of the Western United States. Quaternary Science Reviews 20, 1377-1410. http://doi.org/10.1016/S0277-3791(01)00002-6.

Pandey, G.R., Cayan, D.R., Georgakakos, K.P. 1999. Precipitation structure in the Sierra Nevada of California during winter. Journal of Geophysical Research 104D, 12019-12030. http://doi. org/10.1029/1999JD900103.

Phillips, F.M. 2008. Geological and hydrological history of the paleo-Owens River drainage since the late Miocene. In: M.C. Reheis, R. Hershler, D.M. Miller (Eds.), Late Cenozoic Drainage History of the Southwestern Great Basin and Lower Colorado River Region: Geologic and Biotic Perspectives. Geological Society of America, Boulder, Colorado, pp. 115-150.

Phillips, F.M. 2016. Constraints on cosmogenic nuclide production rates by samples from the Sierra Nevada, California: I. Late Pleistocene glacial chronology. Quaternary Geochronology 35, 119-129.

Phillips, F.M., Argento, D.C., Balco, G., Caffee, M.W., Clem, J.M., Dunai, T.J., Finkel, R., Goehring, B., Gosse, J.C., Hudson, A., Jull, A.J.T., Kelly, M., Kurz, M.D., Lal, D., Lifton, N., Marrero, S.M., Nishiizumi, K., Reedy, R., Schaefer, J., Stone, J.O.H., Swanson, T., Zreda, M.G. 2016a. The CRONUS-Earth Project: A synthesis. Quaternary Geochronology 31, 119154. http://doi.org/10.1016/j.quageo.2015.09.006.

Phillips,F.M.,Campbell,A.R., Kruger,C., Johnson,P., Roberts, R., Keyes, E. 1992.A reconstruction of the response of the water balance in western United States lake basins to climatic change. New Mexico Water Resources Research Institute, Las Cruces, New Mexico, p. 167.

Phillips, F.M., Campbell, A.R., Smith, G.I., Bischoff, J.L. 1994. Interstadial climatic cycles: A link between western North America and Greenland? Geology 22, 1115-1118.

Phillips, F.M., Hinz, M., Marrero, S.M., Nishiizumi, K. 2016b. Constraints on cosmogenic nuclide production rates by samples from the Sierra Nevada, California: II. Sample sites and evaluation. Quaternary Geochronology 35, 101-118. http://doi.org/10.1130/00917613(1994)022<1115:ICCALB >2.3CO;2.

Phillips, F.M., Zreda, M., Plummer, M.A., Elmore, D., Clark, D.H. 2009. Glacial geology and chronology of Bishop Creek and vicinity, eastern Sierra Nevada, California. Geological Society of America Bulletin 121, 1013-1033. http://doi.org/10.1130/B26271.1.

Phillips, F.M., Zreda, M.G., Benson, L.V., Plummer, M.A., Elmore, D., Sharma, P. 1996. Chronology for fluctuations in late Pleistocene Sierra Nevada glaciers and lakes. Science 274, 749-751. http://doi.org/10.1126/science.274.5288.749.

Phillips, F.M., Zreda, M.G., Smith, S.S., Elmore, D., Kubik, P.W., Sharma, P. 1990. Cosmogenic chlorine-36 chronology for glacial deposits at Bloody Canyon, eastern Sierra Nevada. Science 248, 1529-1532. http://doi.org/10.1126./science.248.4962.1529.

Plummer, M.A. 2002. Paleoclimatic conditions during the last deglaciation inferred from combined analysis of pluvial and glacial records. Earth \& Environmental Science, New Mexico Institute of Mining \& Technology, Socorro, 308 pp. 
Plummer, M.A., Phillips, F.M. 2003. A 2-D numerical model of snow/ice energy balance and ice flow for paleoclimatic interpretation of glacial geomorphic features. Quaternary Science Reviews 22, 1389-1406. http://doi.org/10.1016/S0277-3791(03)00081-7.

Porter, S.C. 1964. Composite Pleistocene snowline of Olympic Mountains and Cascade Range, Washington. Geological Society of America Bulletin 75, 477-482.

Putnam, W.C. 1950. Moraine and shoreline relationships at Mono Lake, California. Geological Society of America Bulletin 61, 116-122.

Raub, W., Brown, C.S., Post, A. 2006. Inventory of glaciers in the Sierra Nevada, California. U.S. Geological Survey Open-File Report 2006-1239, p. 228.

Reheis, M.C., Adams, K.D., Oviatt, C.G., Bacon, S.N. 2014. Pluvial lakes in the western United States - A view from the outcrop. Quaternary Science Reviews 97, 33-57. http://doi. org/10.1016/j.quascirev.2014.04.012.

Reimer, P.J., Bard, E., Bayliss, A., Beck, J.W., Blackwell, P.G., Bronk Ramsey, C., Buck, C.E., Cheng, H., Edwards, R.L., Friedrich, M., Grootes, P.M., Guilderson, T.P., Haflidason, H., Hajdas, I., Hatté, C., Heaton, T.J., Hoffmann, D.L., Hogg, A.G., Hughen, K.A., Kaiser, K.F., Kromer, B., Manning, S.W., Niu, M., Reimer, R.W., Richards, D.A., Scott, E.M., Southon, J.R., Staff, R.A., Turney, C.S.M., van der Plicht, J. 2013. IntCal13 and Marine13 radiocarbon age calibration curves 0-50,000 years cal BP. Radiocarbon 55 (4), 1869-1887. https://doi. org/10.2458/azu_js_rc.55.16947.

Rinehart, C.D. 1964. Geology and mineral deposits of the Mount Morrison quadrangle, Sierra Nevada, California. U.S. Geological Survey Professional Paper 385, 106 pp.

Rood, D.H., Burbank, D.W., Finkel, R.C. 2011. Chronology of glaciations in the Sierra Nevada, California, from ${ }^{10} \mathrm{Be}$ surface exposure dating. Quaternary Science Reviews 30, 646-661. http://doi.org/10.1016/j.quascirev.2010.12.001.

Russell, I.C. 1889. Quaternary history of Mono Valley, California. Eighth Annual Report of the United States Geological Survey, pp. 267-394.

Schaefer, J.M., Denton, G.H., Barrell, D.J.A., Ivy-Ochs, S., Kubik, P.W., Andersen, B.G., Phillips, F.M., Lowell, T.V., Schluchter, C. 2006. Near-synchronous interhemispheric termination of the Last Glacial Maximum in mid-latitudes. Science 312, 1510-1513. http://doi.org/10.1126/ science.1122872.

Shakun, J.D., Clark, P.U., He, F., Lifton, N.A., Liu, Z., Otto-Bliesner, B.L. 2015. Regional and global forcing of glacier retreat during the last deglaciation. Nature Communications 6, 8059 . http://doi.org/10.1038/ncomms9059.

Sharp, R.P. 1969. Semiquantitative differentiation of glacial moraines near Convict Lake, California. Journal of Geology 77, 68-91. http://www.jstor.org/stable/30062239.

Sharp, R.P., Birman, J.H. 1963. Additions to classical sequence of Pleistocene glaciations, Sierra Nevada, California. Geological Society of America Bulletin 74, 1079-1086.

Small, E.E., Anderson, R.S. 1995. Geomorphically driven late Cenozoic rock uplift in the Sierra Nevada, California. Science 270, 277-280. http://doi.org/10.1126/science,270.5234.277.

Smith, G.I. 1987. Searles Valley, California: outcrop evidence of a Pleistocene lake and its fluctuations, limnology, and climatic significance. In: M.L. Hill (Ed.), Centennial Field Guide, Cordilleran Section, Vol. 1. Geological Society of America, Boulder, Colorado, pp. 137-142.

Smith G.I. 2009. Late Cenozoic geology and lacustrine history of Searles Valley, Inyo and San Bernadino Counties, California. U.S. Geological Survey Professional Paper 1727.

Stuiver, M., Reimer, P.J. 1993. Extended ${ }^{14} \mathrm{C}$ data base and revised CALIB $3.0{ }^{14} \mathrm{C}$ age calibration program. Radiocarbon 35, 215-230. http://doi.org/10.1017/S0033822200013904.

Stuiver, M., Smith, G.I. 1979. Radiocarbon ages of stratigraphic units. In: G.I. Smith (Ed.), Substuface stratigraphy and geochemistry of Late Quaternary evaporites, Searles Lake, California. U.S. Geological Survey, Professional Paper 1043, pp. 68-73. 
Toucanne, S., Soulet, G., Freslon, N., Silva Jacinto, R., Dennielou, B., Zaragosi, S., Eynaud, F., Bourillet, J.-F., Bayon, G. 2015. Millennial-scale fluctuations of the European Ice Sheet at the end of the last glacial, and their potential impact on global climate. Quaternary Science Reviews 123, 113-133. http://doi.org/10.1016/j.quascirev.2015.06.010.

Turner, H.W. 1900. The Pleistocene geology of the south-central Sierra Nevada with especial reference to the orign of Yosemite Valley. California Academy of Sciences Proceedings, Geology 3, 261-321.

Ullman, D.J., Carlson, A.E., Anslow, F.S., LeGrande, A.N., Licciardi, J.M. 2015. Laurentide ice-sheet instability during the last deglaciation. Nature Geoscience 8, 534-537. http://doi. org/10.1038/ngeo2463.

Wahrhaftig, C., Birman, J.H. 1965. The Quaternary of the Pacific mountain system in California. In: H.E. Wright, Jr., D.G. Frey (Eds.), The Quaternary of the United States. Princeton University Press, Princeton, New Jersey, pp. 299-340.

Wells, P.V. 1979. An equitable glaciopluvial in the west: Pleniglacial evidence of increased precipitation on a gradient from the Great Basin to the Sonoran and Chihuahuan deserts. Quaternary Research 12, 311-325.

Zaragosi, S., Eynaud, F., Pujol, C., Auffret, G.A., Turon, J.L., Garlan, T. 2001. Initiation of the European deglaciation as recorded in the northwestern Bay of Biscay slope environments (Meriadzek Terrace and Trevelyan Escarpment): a multi-proxy approach. Earth and Planetary Science Letters 188, 493-507. http://doi.org/10.1016/S0012-821X(01)00332-6. 